\title{
Arsenic Trioxide Inhibits Human T Cell-Lymphotropic Virus-1-Induced Syncytiums by Down-Regulating gp46
}

\author{
Hiromi Nabeshi,${ }^{a, b}$ Tomoaki Yoshikawa, ${ }^{a, b}$ Haruhiko Kamada, ${ }^{a, c}$ Hiroko ShiBata,,${ }^{a, b}$ Toshiki Sugita,,${ }^{a, b}$

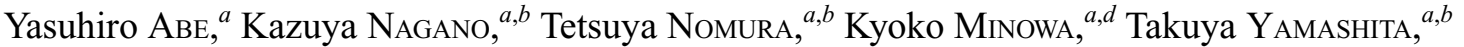 \\ Norio Itoh, ${ }^{a, b}$ Yasuo Yoshioke, ${ }^{a, c}$ Shin-ichi TsunOdA, ${ }^{*, a, c}$ and Yasuo Tsutsumi ${ }^{a, b, c}$ \\ ${ }^{a}$ Laboratory of Pharmaceutical Proteomics, National Institute of Biomedical Innovation; 7-6-8 Saito-Asagi, Ibaraki, \\ Osaka 567-0085, Japan: ${ }^{b}$ Graduate School of Pharmaceutical Sciences, Osaka University; ${ }^{c}$ The Center for Advanced \\ Medical Engineering and Informatics, Osaka University; 1-6 Yamadaoka, Suita, Osaka 565-0871, Japan: and \\ ${ }^{d}$ Department of Biopharmaceutics, Kyoto Pharmaceutical University; 5 Misasagi-Nakauchicho, Yamashina-ku, Kyoto \\ 607-8414, Japan. Received January 16, 2009; accepted May 8, 2009: published online May 11, 2009
}

\begin{abstract}
Adult T-cell leukemia (ATL) is a severe chemotherapy-resistant malignancy associated with prolonged infection by the human T cell-lymphotropic virus 1 (HTLV-1). One approach to prevent the onset of ATL is to inhibit the growth/transmission of HTLV-1 infected cells using arsenic trioxide $\left(\mathrm{As}_{2} \mathrm{O}_{3}\right)$. However, there are no reports on the transmission inhibitory effect of $\mathrm{As}_{2} \mathrm{O}_{3}$. In this study, we reveal that $\mathrm{As}_{2} \mathrm{O}_{3}$ exerts an inhibitory effect on syncytium formation between HTLV-1 infected MT-2 and HeLa cells. In addition, Western blot analysis revealed that the HTLV-1 derived envelope protein gp46 was down regulated by $\mathrm{As}_{2} \mathrm{O}_{3}$ treatment, suggesting that $\mathrm{As}_{2} \mathrm{O}_{3}$ may inhibit HTLV-1 virus transmission via down-regulation of gp46. These results suggest that $\mathrm{As}_{2} \mathrm{O}_{3}$ may be a promising drug to treat refractory HTLV-1-related diseases.
\end{abstract}

Key words adult T-cell leukemia; human T cell-lymphotropic virus 1; arsenic trioxide; syncytium

Human T-cell leukemia virus type 1 (HTLV-1) is the etiologic agent of adult T-cell leukemia (ATL). ${ }^{1,2)}$ ATL is characterized by malignant lympho-proliferation of mature activated $\mathrm{T}$ cells, predominantly CD4-positive T cells. This proliferation develops after a long period of latency following HTLV-1 infection. It is currently estimated that there are about twenty million HTLV-1 carriers worldwide. Of these, around $5 \%$ are at risk for ATL onset, and it has been reported that the incidence of ATL has been increasing. Epidemiological studies have indicated strongly that an increased HTLV-1 virus load is an important factor in ATL onset, although the detailed mechanisms of ATL onset are unknown. Therefore, an ideal anti-ATL agent would have both a growth inhibitory effect on ATL cells and an inhibitory effect on transmission of HTLV-1-infected cells. $\mathrm{As}_{2} \mathrm{O}_{3}$ show promising results in the treatment of patients with ATL in combination with interferon (IFN)- $\alpha .^{3-8)}$ Although $\mathrm{As}_{2} \mathrm{O}_{3}$-induced apoptosis is thought to play a major role in its observed therapeutic growth inhibitory effects in treating $\mathrm{ATL}^{9,10)}$ the effects of $\mathrm{As}_{2} \mathrm{O}_{3}$ on HTLV-1 infection/transmission have not been reported.

HTLV-1 can be distinguished from all other retroviruses on the basis of the infection process: it is transmitted almost exclusively via cell-to-cell contact and cell-to-cell fusion (also termed syncytium formation), and the free viral particle is very poorly infectious. ${ }^{11)}$ The HTLV-1 envelope glycoprotein is synthesized as a $61-\mathrm{kDa}$ precursor that is cleaved into cellsurface (gp46) and transmembrane (gp21) proteins ${ }^{12,13)}$ and the gp46 product is thought to play an important role as the virus attachment protein. HTLV-1 can induce syncytium formation between infected cells and certain uninfected cell types ${ }^{14,15)}$ but this process can be blocked by antibodies against the gp46 protein or against gp46-derived peptides. $^{16,17)}$ Thus, gp46 is a key protein for HTLV-1 transmission via syncytium formation, which is a critical process for HTLV-1 transmission via cell-to-cell contact.
In the present study, we reveal that HTLV-1-induced syncytium formation can be blocked by $\mathrm{As}_{2} \mathrm{O}_{3}$ treatment. Western blot analysis indicated that gp46 was down-regulated by $\mathrm{As}_{2} \mathrm{O}_{3}$ treatment. Our results suggest that $\mathrm{As}_{2} \mathrm{O}_{3}$ can prevent the HTLV-1 transmission by reducing levels of gp46, in addition to its therapeutic effect on ATL by promoting apoptosis. These results suggested that $\mathrm{As}_{2} \mathrm{O}_{3}$ may open new avenues for treating HTLV-1-related diseases, including ATL.

\section{MATERIALS AND METHODS}

Cell Culture The HTLV-1-infected cell line MT-2 (a kind gift from Hayashibara Biochemical Laboratories, Inc.) was grown in RPMI-1640 (Wako Pure Chemical Industries, Ltd., Osaka, Japan) supplemented with 10\% heat-inactivated fetal calf serum and 1\% Antibiotic-Antimycotic Mix stock solution (Nacalai Tesque, Osaka, Japan) in a humidified atmosphere of $95 \%$ air $/ 5 \% \mathrm{CO}_{2}$, at $37^{\circ} \mathrm{C}$. A HeLa cell line was maintained in minimum essential medium (MEM- $\alpha$; Wako) supplemented with $10 \%$ heat-inactivated fetal calf serum and 1\% Antibiotic-Antimycotic Mix stock solution.

Detection of Syncytium Formation HeLa cells were plated at $8.0 \times 10^{4}$ cells per well onto 12 -well plates (Corning, NY, U.S.A.) and incubated for $36 \mathrm{~h}$. MT-2 cells were preincubated for $12 \mathrm{~h}$ with or without $\mathrm{As}_{2} \mathrm{O}_{3}$, following irradiation at 12000 rads. $\mathrm{As}_{2} \mathrm{O}_{3}$-treated and irradiated HTLV-1-infected cells were then added to HeLa cells seeded into a 12well plate at a concentration of $8.0 \times 10^{4}$ viable cells per well. After $24 \mathrm{~h}$ co-culture, MT- 2 cells were removed by washing with pre-warmed culture medium, and $200 \mu \mathrm{l}$ of Hoechst 33342 (Dojindo, Kumamoto, Japan; $20 \mu \mathrm{g} / \mathrm{ml}$ ) and $40 \mu \mathrm{l}$ of CFSE (Dojindo; $100 \mu \mathrm{g} / \mathrm{ml}$ ) were added to stain the nuclei and cytoplasm, respectively. After fixing with $4 \%$ paraformaldehyde, cells were analyzed using an ImageXpress $^{\mathrm{MICRO}}$ High Content Screening System (Molecular Devices, Sunnyvale, CA, U.S.A.) and a fluorescence micro- 
scope. Syncytia containing $>5$ nuclei per cell were counted in triplicate wells.

Western Blots to Detect gp46 MT-2 was solubilised in IP lysis buffer (25 mм Tris- $\mathrm{HCl} \mathrm{pH} 7.4,100 \mathrm{~mm} \mathrm{NaCl}, 2 \mathrm{~mm}$ ethylenediaminetetraacetic acid (EDTA), 0.5\% (w/v) Triton $\mathrm{X}-100,0.1 \%(\mathrm{v} / \mathrm{v})$ protease inhibitor cocktail (Sigma, St. Louis, MO, U.S.A.)). $2.5 \mu \mathrm{g}$ of cell lysates were subjected to SDS-polyacrylamide gel electrophoresis and transferred to a PVDF membrane. The proteins were visualized by immunoblot analysis; primary and secondary antibodies were anti-HTLV-1 gp46 antibody (ZeptoMetrix, Buffalo, NY, U.S.A.; $1: 5000$ dilution) and peroxidase-conjugated antimouse IgG (H+L-chain) (MBL; $1: 10000$ dilution), respectively. As a loading control, beta actin was detected using anti-beta actin antibody (GeneTex, San Antonio, TX, U.S.A.; $1: 80000$ dilution).

\section{RESULTS AND DISCUSSION}

The infectivity of free HTLV-1 tends to be very poor, and the virus appears to be transmitted most efficiently by the cell-to-cell route. HTLV-1 infection is dependent upon the viral envelope glycoprotein-catalyzed fusion of the viral and cellular membranes. ${ }^{18)}$ Like many other retroviruses, HTLV-1 can induce syncytium formation between infected cells and certain uninfected cell types. Thus, to determine whether $\mathrm{As}_{2} \mathrm{O}_{3}$-treatment inhibits HTLV-1 transmission, we first carried out a syncytium formation assay using $\mathrm{As}_{2} \mathrm{O}_{3}$-treated MT-2 cells and uninfected HeLa cells. As shown in Figs. 1A and $\mathrm{B}$, a significant number of syncytia were observed when untreated MT-2 cells were co-cultured with HeLa cells. In contrast, this syncytium formation was significantly de-

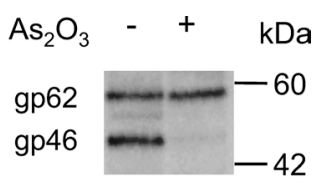

beta actin

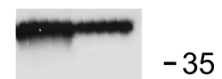

Fig. 2. $\mathrm{As}_{2} \mathrm{O}_{3}$ Treatment Down-Regulates gp46 Expression

Expression of gp46 and gp62 in untreated MT-2 cells and in MT- 2 cells treated with $\mathrm{As}_{2} \mathrm{O}_{3}$ was detected by Western blot. $\beta$-Actin was used as a loading control. creased when MT-2 cells were pre-treated with $10 \mu \mathrm{M} \mathrm{As} \mathrm{O}_{2} \mathrm{O}_{3}$. The number of syncytia per field was 100 in $\mathrm{As}_{2} \mathrm{O}_{3}$-untreated MT-2 cells, but only 10 syncytia were observed in $10 \mu \mathrm{M}$ $\mathrm{As}_{2} \mathrm{O}_{3}$-treated cultures. We also assessed the viability of $10 \mu \mathrm{M} \mathrm{As} \mathrm{O}_{2} \mathrm{O}_{3}$-treated MT-2 cells by WST- 8 assay, and results indicated that there were no significant cytotoxicities (data not shown). Collectively, these results suggested that $\mathrm{As}_{2} \mathrm{O}_{3}$ had an inhibitory effect on syncytium formation mediated by HTLV-1 infected cell lines without inducing cytotoxicity.

It has been reported that the HTLV-1 envelope protein gp46 interacts with GLUT1, HSC70 and heparin sulfate. These interactions play an important role in HTLV-1 transmission via cell-to-cell contact between HTLV-1 infected cells. ${ }^{19-24)}$ Therefore, we next performed Western blots using an anti-gp46 antibody to determine whether the expression level of gp46, a key protein involved in HTLV-1 transmission, was changed by $\mathrm{As}_{2} \mathrm{O}_{3}$ treatment. The gp46 expression level was significantly decreased in the MT-2 cell lines by $\mathrm{As}_{2} \mathrm{O}_{3}$ treatment, indicating that $\mathrm{As}_{2} \mathrm{O}_{3}$ treatment suppressed gp46 production. The HTLV-1 envelope protein is synthesized as a precursor protein (gp62), which is subsequently cleaved to a surface protein (gp46) and a transmembrane protein (gp21). ${ }^{12,13)}$ Gp62 is modified by glycosylation events, proteolytically cleaved and inserted into the host cell membrane during virus particle assembly and release. ${ }^{25,26)}$ It has been reported that inhibition of glycosylation, which is regulated by molecular chaperones, prevents both gp62 cleavage and syncytium formation. ${ }^{25,27-29)}$ Because $\mathrm{As}_{2} \mathrm{O}_{3}$ treatment suppresses gp46 but not gp62 (Fig. 2), we speculated that it might inactivate the chaperone machinery. To clarify these mechanisms, we are now carrying out a proteomic analysis of $\mathrm{As}_{2} \mathrm{O}_{3}$-treated MT-2 cells. Previous reports ${ }^{25,27-29)}$ indicated that as one of the factors of down-regulation of gp46 by $\mathrm{As}_{2} \mathrm{O}_{3}$ treatment was caused by oxidation of protein chaperones causing their dysfunction, leading to suppression of gp46 production. These findings contradict the observations of Andrews et al., who reported that $\mathrm{Na}$ arsenite shock results in an increase in syncytium formation and gp62 expression. $\mathrm{As}_{2} \mathrm{O}_{3}$ reportedly exerts dose-dependent dual effects on APL. Therefore, the 8-fold difference in the arsenic ion concentration between their methods and our methods might influence the cellular responses.

In summary, we have demonstrated that $\mathrm{As}_{2} \mathrm{O}_{3}$ can inhibit HTLV-1 mediated syncytium formation, and that this is prob-
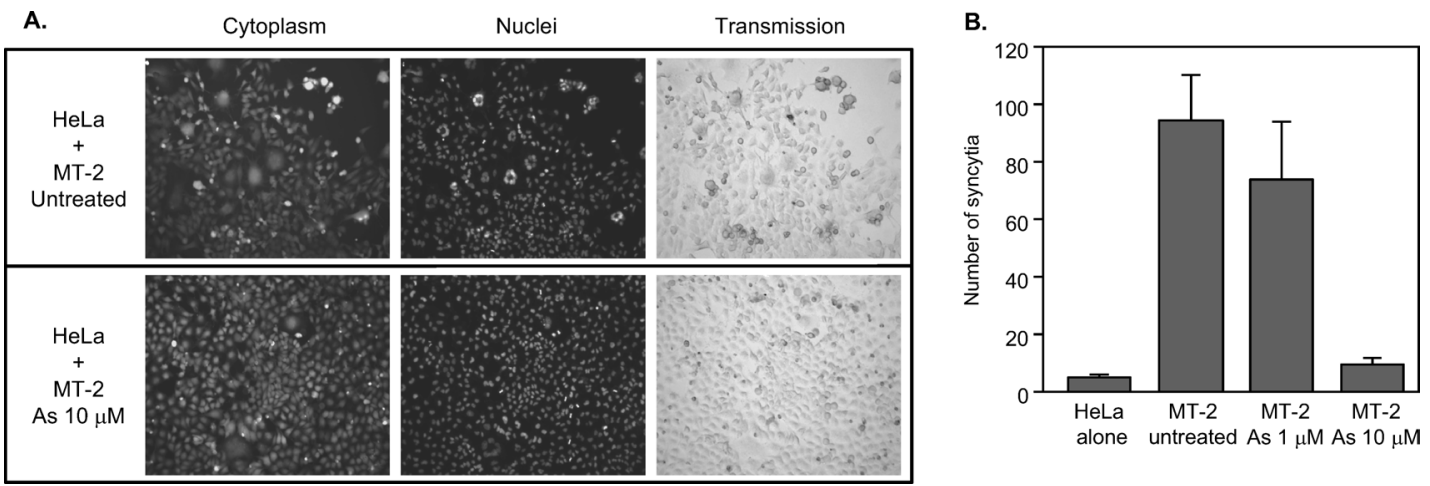

Fig. 1. Syncytium Formation Assay

Irradiated HeLa cells were co-cultured with MT-2 cells (A, B), which were pre-incubated with or without $\mathrm{As}_{2} \mathrm{O}_{3}$. Nuclei and cytoplasm were stained with Hoechst 33342 and CFSE, respectively. (A) The effect of $\mathrm{As}_{2} \mathrm{O}_{3}$ on syncytium formation was observed under a fluorescence microscope $(\times 100)$. (B) The number of syncytia containing $>5$ nuclei is the average of total syncytia per $147 \mathrm{~mm}^{2}$ measured in three separate wells. The data represent means and S.D.s of triplicate wells. 
ably due to suppression of gp46 production. Although more detailed studies are necessary to elucidate the causes of the observed effect on HTLV-1 transmission, it appears that dysfunction of chaperone proteins might contribute to the inhibitory effect of $\mathrm{As}_{2} \mathrm{O}_{3}$ treatment on syncytium formation. Thus, we indicated that $\mathrm{As}_{2} \mathrm{O}_{3}$ could inhibit HTLV-1 transmission as well as induce apoptosis to ATL cells. Because $\mathrm{As}_{2} \mathrm{O}_{3}$ have carcinogenesis, it is necessary for safety use of $\mathrm{As}_{2} \mathrm{O}_{3}$ to study the syncytium inhibition effect at low concentration. But, we believe that this study provides pertinent information related to the targeted discovery of drugs to treat ATL.

Acknowledgements This study was supported in part by some Grants-in-Aid for Scientific Research from the Ministry of Education, Culture, Sports, Science and Technology of Japan and Japan Society for the Promotion of Science (JSPS). And this study was also supported in part by some Health Labour Sciences Research Grants from the Ministry of Health, Labor and Welfare of Japan, in part by Health Sciences Research Grants for Research on Health Sciences focusing on Drug Innovation from the Japan Health Sciences Foundation. Finally, we would like to thank to the support form JSPS Research Fellowships for Young Scientists (No. 202324).

\section{REFERENCES}

1) Hinuma Y., Nagata K., Hanaoka M., Nakai M., Matsumoto T., Kinoshita K. I., Shirakawa S., Miyoshi I., Proc. Natl. Acad. Sci. U.S.A., 78, 6476-6480 (1981).

2) Takatsuki K., Yamaguchi K., Kawano F., Hattori T., Nishimura H., Tsuda H., Sanada I., Princess Takamatsu Symp., 15, 51—57 (1984).

3) Hermine O., Dombret H., Poupon J., Arnulf B., Lefrere F., Rousselot P., Damaj G., Delarue R., Fermand J. P., Brouet J. C., Degos L., Varet B., de The H., Bazarbachi A., Hematol. J., 5, 130-134 (2004).

4) Nasr R., Rosenwald A., El-Sabban M. E., Arnulf B., Zalloua P., Lepelletier Y., Bex F., Hermine O., Staudt L., de The H., Bazarbachi A., Blood, 101, 4576-4582 (2003).

5) Mahieux R., Pise-Masison C., Gessain A., Brady J. N., Olivier R., Perret E., Misteli T., Nicot C., Blood, 98, 3762-3769 (2001).

6) El-Sabban M. E., Nasr R., Dbaibo G., Hermine O., Abboushi N., Quignon F., Ameisen J. C., Bex F., de The H., Bazarbachi A., Blood, 96, 2849-2855 (2000).
7) Bazarbachi A., El-Sabban M. E., Nasr R., Quignon F., Awaraji C., Kersual J., Dianoux L., Zermati Y., Haidar J. H., Hermine O., de The H., Blood, 93, 278-283 (1999).

8) Ishitsuka K., Hanada S., Suzuki S., Utsunomiya A., Chyuman Y., Takeuchi S., Takeshita T., Shimotakahara S., Uozumi K., Makino T., Arima T., Br. J. Haematol., 103, 721-728 (1998).

9) Zhu J., Chen Z., Lallemand-Breitenbach V., de The H., Nat. Rev. Cancer, 2, 705-713 (2002).

10) Zhu Q., Zhang J. W., Zhu H. Q., Shen Y. L., Flexor M., Jia P. M., Yu Y., Cai X., Waxman S., Lanotte M., Chen S. J., Chen Z., Tong J. H., Blood, 99, 1014-1022 (2002).

11) Donegan E., Lee H., Operskalski E. A., Shaw G. M., Kleinman S. H., Busch M. P., Stevens C. E., Schiff E. R., Nowicki M. J., Hollingsworth C. G., Transfusion, 34, 478-483 (1994).

12) Hattori S., Kiyokawa T., Imagawa K., Shimizu F., Hashimura E., Seiki M., Yoshida M., Virology, 136, 338-347 (1984).

13) Schneider J., Yamamoto N., Hinuma Y., Hunsmann G., Virology, 132, $1-11(1984)$

14) Hoshino H., Shimoyama M., Miwa M., Sugimura T., Proc. Natl. Acad. Sci. U.S.A., 80, 7337-7341 (1983).

15) Nagy K., Clapham P., Cheingsong-Popov R., Weiss R. A., Int. J. Cancer, 32, 321-328 (1983)

16) Brighty D., W. Jassal S. R., J. Virol., 75, 10472-10478 (2001)

17) Tanaka Y., Zeng L., Shiraki H., Shida H., Tozawa H., J. Immunol., 147, 354-360 (1991).

18) Jassal S. R., Lairmore M. D., Leigh-Brown A. J., Brighty D. W., Virus Res., 78, 17-34 (2001).

19) Manel N., Kim F. J., Kinet S., Taylor N., Sitbon M., Battini J. L., Cell, 115, 449-459 (2003).

20) Coskun A. K., Sutton R. E., J. Virol., 79, 4150-4158 (2005).

21) Fang D., Haraguchi Y., Jinno A., Soda Y., Shimizu N., Hoshino H., Biochem. Biophys. Res. Commun., 261, 357-363 (1999).

22) Sagara Y., Ishida C., Inoue Y., Shiraki H., Maeda Y., J. Virol., 72, 535-541 (1998)

23) Sagara Y., Inoue Y., Kojima E., Ishida C., Shiraki H., Maeda Y., AIDS Res. Hum. Retroviruses, 17, 125-135 (2001).

24) Pinon J. D., Klasse P. J., Jassal S. R., Welson S., Weber J., Brighty D. W., Sattentau Q. J., J. Virol., 77, 9922-9930 (2003).

25) Paine E., Gu R., Ratner L., Virology, 199, 331-338 (1994).

26) Pique C., Pham D., Tursz T., Dokhelar M. C., J. Virol., 66, 906-913 (1992).

27) Earl P. L., Moss B., Doms R. W., J. Virol., 65, 2047-2055 (1991).

28) Otteken A., Earl P. L., Moss B., J. Virol., 70, 3407-3415 (1996).

29) Land A., Braakman I., Biochimie, 83, $783-790$ (2001).

30) Andrews J. M., Oglesbee M. J., Trevino A. V., Guyot D. J., Newbound G. C., Lairmore M. D., Virology, 208, 816-820 (1995).

31) Miller W. H. Jr., Schipper H. M., Lee J. S., Singer J., Waxman S., Cancer Res., 62, 3893-3903 (2002). 